Acta Technologica Agriculturae 2

Nitra, Slovaca Universitas Agriculturae Nitriae, 2019, pp. 43-47

\title{
EVALUATION OF RICE STRAW YIELD, FIBRE COMPOSITION AND COLLECTION UNDER MEDITERRANEAN CONDITIONS
}

\author{
Javier MATÍAS*, Verónica CRUZ, Antonio García, Diana González \\ Agricultural Research Centre of Extremadura (CICYTEX), Guadajira (Badajoz), Spain
}

\begin{abstract}
Rice straw remains almost unutilised in the majority of cases and is usually burned. Data on rice residue production under European conditions are extremely limited. A detailed assessment of rice biomass yield, partitioning and straw collection was carried out in Spain. Eleven commercial rice varieties were evaluated in 2015, and two baling trials were performed in 2014 and 2015. The average straw yield was $9.7 \mathrm{t} \cdot \mathrm{ha}^{-1}$. Straw yield, biomass partitioning indices and fibre composition varied significantly according to rice variety. Straw to grain ratio and harvest index were 1.00 and 0.50 on average for rough grain, and 1.25 and 0.41 for husked grain. Biomass partitioning indices significantly correlated with grain yield. Mean content of cellulose, hemicellulose, lignin and ash of rice straw was $32.5 \%, 19.8 \%, 6.5 \%$ and $13.7 \%$, respectively. Straw amount of less than $3.0 \mathrm{t} \cdot \mathrm{tha}^{-1}$ can be collected during the baling trials. Rice straw could represent an eco-friendly source of lignocellulosic biomass in Europe, however, in order to achieve this, baling machine improvements and special crop management should be carried out.
\end{abstract}

Keywords: agricultural by-products; baling; biomass partitioning; lignocellulosic biomass; greenhouse gases emissions; rice crop

Rice is one of the most widely grown crops in the world. Total area on which the rice is cultivated is approx. 163 million ha; $88 \%$ of this cultivation area is located in Asia (Moreno-García et al., 2017). World rice production amounts to approx. 618 million tons per year (Rahimi-Ajdadi et al., 2018). In terms of Europe, majority of rice cultivation areas are located in the Mediterranean countries. Total European harvested area amounts to approx. 642,000 ha and is primarily located in Italy and Spain (Moreno-García et al., 2017). Rice cultivation yields three by-products, straw and the residues after grain milling (husk and bran). Straw and husk remain almost unutilised, despite that various studies have been done in the past. The high mineral content is one of the main limitations to their use as animal feed, apart from its high lignocellulose content (Vadiveloo et al., 2009). Collection of rice straw is still a major challenge. Field baling is by far the least expensive method for harvesting and packing rice straw (Hegazy and Snadro, 2016). Straw collection is complicated because rice is usually grown under waterlogged conditions. In the Mediterranean Basin, rice straw is available for baling in autumn, when weather conditions are not suitable for this operation. On the other hand, the incorporation of rice straw into the paddy soil can cause physiological damage to the crop (Dobermann and Fairhurst, 2000; Olk et al., 2000). For these reasons, rice straw is usually burned, emitting $\mathrm{CO}_{2}$ into the atmosphere. Burning of rice straw in the open fields results in air pollution, as well as particulate matter release into the atmosphere (Abraham et al., 2016). Nowadays, one of the main world issues is how to reduce the greenhouse gases emissions (GHGe) in order to mitigate the climate change and ensure sustainable economic growth. The EU tries to find cost-efficient ways to make the European economy more climate-friendly. For example, conversion of crop residues can represent one of vital aspects for sustainable development (Abraham et al., 2016). According to the European Commission roadmap, the GHGe should be cut to $40 \%$ below the 1990 levels by 2030 and to $80 \%$ below the 1990 levels by 2050 (Beloev et al., 2017). Considering all the types of agricultural crop residues, rice straw has been reported to be the most available cellulose source in the world, which makes it interesting for several environmentally friendly applications, like the production of biomaterials, biofuels or high-added value biomolecules (Abraham et al., 2016; Singh et al., 2016). However, accurate quantification of regional scale crop residue represents an essential aspect necessary for designing effective policies and management practices that can contribute toward mitigating GHGe (Fan et al., 2017). Several approaches related to biomass partitioning, like harvest index $(H I)$ or straw/grain $(S / G)$ ratio, are widely used to estimate the crop residue from data on harvested yield. Nevertheless, data on rice fibrous byproducts production under European conditions are extremely sparse.

Thus, the aim of this work was to conduct a detailed assessment of rice biomass yield and partitioning and collection and fibre composition of straw under Mediterranean conditions.

\section{Material and methods}

\section{Experimental field trial}

An experimental field trial was carried out during 2015 at the experimental plots of CICYTEX in order to evaluate the straw

Contact address: Javier Matías, Agricultural Research Centre of Extremadura (CICYTEX), 06187 Guadajira (Badajoz), Spain, e-mail: javier.matias@juntaex.es 
yield $(S)$ and to determine the biomass partitioning indices (BPI) and straw composition according to their respective variety. Experimental design was a complete randomized blocks with four replications and experimental plot size was $10.0 \times 1.5 \mathrm{~m}$. Sowing was conducted in mid-May at a density of 600 seeds per $\mathrm{m}^{2}$. Average characteristics of the soil at 0-0.6 m depth were: clay loam texture, $\mathrm{pH} 6.2,0.87 \%$ of organic matter, $88.5 \mathrm{ppm}$ of nitrate, $14.8 \mathrm{ppm}$ of phosphorus and $69.2 \mathrm{ppm}$ of potassium. Eleven commercial rice varieties were evaluated, a hybrid (CLXL745) plus 10 inbred lines. Crop was maintained under flooding. A 200-120-120 kg $\cdot \mathrm{ha}^{-1}$ of NPK was applied. In the beginning of October, crop was mowed by hand at ground level and the grain was separated mechanically from the rest of biomass using a thresher.

\section{Baling trials}

Two baling trials were conducted on October 30, 2014, and on December 3, 2015, in an open rice field located in the Upper Guadiana River Basin of Extremadura (Southwest Spain). Rice harvest was previously carried out using a combine harvester, distributing the straw in windrows separated at the working width $(6.5 \mathrm{~m})$. Plants were cut approx. $0.25 \mathrm{~m}$ above the ground level. The variety was Gladio. A lineal metre of straw on the windrows was taken in four randomized points to determine the available straw for baling. The main characteristics of the baling machine (John Deere, 359 model) are $1.42 \mathrm{t}$ of weight, $1.75 \mathrm{~m}$ of picker and bales of $0.46 \mathrm{~m}$ width and $0.36 \mathrm{~m}$ height. A tractor of $82 \mathrm{KW}$ and $5.2 \mathrm{t}$ weight with narrow rubber tires was used. Baling yield (\%) was calculated as the baled straw in relation to the available straw for baling. After baling, 5 randomized bales were weighed and measured.

\section{Measurements}

Data were expressed on dry weight basis. Dry matter content was determined by drying the samples at $103^{\circ} \mathrm{C}$ over three days. Biomass (B) corresponds to the total aboveground biomass dry matter. Following BPI were used: ratio between straw and grain yield $(S / G)$ and harvest index $(H I)$, which was calculated as the $\mathrm{G} / \mathrm{B}$ ratio, and is related to $S / G$ by:

$$
H I=1 /(1+S / G)
$$

Rice husk content was determined using a laboratory paddy husker (Satake, Japan). Fibre content and composition (crude fibre, CF; neutral detergent fibre, NDF; acid detergent fibre, ADF and acid detergent lignin, ADL) were analysed following the Ankom procedure. Hemicellulose $(\mathrm{H})$ content was determined by deducting ADF from NDF. Cellulose content $(C)$ was calculated by deducting ADL from ADF. Ash level was measured as the residue remaining after heating at $550^{\circ} \mathrm{C} \pm 10^{\circ} \mathrm{C}$. Relative Feed Value (RFV) was calculated as Digestible Dry Matter (DDM) multiplied by dry matter intake (DMI as \% of Body Weight) and divided by 1.29 , where $\mathrm{DDM}=88.9-(0.779 \times \% \mathrm{ADF})$ and $\mathrm{DMI}=120 /(\% \mathrm{NDF})$.

\section{Statistical analysis}

Measured and calculated data were subjected to analysis of variance (ANOVA). In cases when $F$ ratio was significant $(P<0.05)$, Tukey's test was utilized for mean comparison. Linear regression model was used to study relationships between BPI and G. An analysis of covariance (ANCOVA) was performed in order to observe potential influence of variety and yield on BPI, taking variety as factor and yield as covariate. SPSS statistical software was used.

\section{Results and discussion}

\section{Experimental field trial}

\section{Straw yield and biomass partitioning}

Results are shown in Table 1. S and BPI varied significantly on the basis of the respective varieties. The average $\mathrm{S}$ was $9.7 \mathrm{t} \cdot \mathrm{ha}^{-1}$. It should be noted that such $\mathrm{S}$ is more than two times as much as usually obtained from wheat under Mediterranean conditions (Townsend et al., 2017) and close to that of maize, another summer cereal widely cultivated in Mediterranean regions, at G of $10 \mathrm{t} \cdot \mathrm{ha}^{-1}$ (Junta de Extremadura, 2017) and $H I$ for maize of 0.50 (Fan et al., 2017; Ion et al., 2015). Different results have been reported for rice in other parts of the world. A higher S (11.8 th.ha $\left.{ }^{-1}\right)$, but similar $\mathrm{G}\left(9.5 \mathrm{t} \cdot \mathrm{ha}^{-1}\right)$, was obtained on average by Osorio et al. (2007), who evaluated 14 rice varieties under tropical conditions. This is consistent with that reported by Hay (1995), who pointed out that $G$ is not correlated with B in rice. In fact, no significant relationship was found between $G$ and $S$. Thus, Marquesa variety achieved the highest $G$ $\left(10.5 \mathrm{t} \cdot \mathrm{ha}^{-1}\right)$ and the lowest $\mathrm{S}\left(8.8 \mathrm{t} \cdot \mathrm{ha}^{-1}\right)$.

The highest $B$ was achieved by the hybrid CLXL $745\left(22.2 \mathrm{t} \cdot \mathrm{ha}^{-1}\right)$, which showed relatively low biomass partitioning. This result is not consistent with that reported by several authors who pointed out that hybrid rice have higher $G$ than inbred lines due to a higher partitioning efficiency (Amanullah and Inamullah, 2016; Bueno and Lafarge, 2009). The $S / G$ ranged from 0.79 to 1.59 . Osorio et al. (2007) also determined a significant influence of variety on $S / G$, which varied from 0.84 to 2.00 . The $H I$ varied from 0.39 to 0.56 , which is in accordance with results reported for different world places, such as India (Singh et al., 2017), Japan (Hussain et al., 2014), Brazil (Fageria et al., 2011), USA-Florida (Prasad et al., 2006), USA-Texas (Kiniry et al., 2001). Significant relationship $(P<0.01)$ between both BPI and $G$ was determined, although less than $30 \%$ of the BPI variation could be explained by G. However, the ANCOVA result indicated that the variety factor had a significant influence. Taking into account the pairwise comparison of the ANCOVA, if the varieties showing extreme values of both BPI (Gavella and Creso) were not taken into account, relationships were not significantly influenced by variety, and could be more useful for rice crop residue estimation. Results of that linear regression analysis were: $S / G=$ $1.637-0.067 G\left(R^{2}=0.25\right)$ and $H I=0.357+0.015 G\left(R^{2}=\right.$ $0.24)$. It should be noted that this HI-G relationship is quite similar to that obtained for wheat by Fan et al. (2017). Those BPI were calculated considering rough rice without husk removal, which is very substantial. Average husk content was $19.1 \%$, which is similar to that $(20.0 \%)$ reported by Hay (1995), and was significantly influenced by variety (Table 1). Therefore, comparison with indices of other crops with bare grains would be inadequate. When husked grain $(G)$ was considered, mean harvest index $\left(H I^{\prime}\right)$ was 0.41 , which 
Table 1 Straw yield and biomass partitioning according to variety

\begin{tabular}{|c|c|c|c|c|c|c|c|c|}
\hline Variety & $G\left(t \cdot h a^{-1}\right)$ & $S\left(t \cdot h a^{-1}\right)$ & $S / G$ & $B\left(t \cdot h a^{-1}\right)$ & $H I$ & $H^{\prime}$ & Husk (\% G) & Husk (t.ha $\left.{ }^{-1}\right)$ \\
\hline Gavella & 8.1 & $12.9 a$ & $1.59 a$ & 21.1 & $0.39 \mathrm{~b}$ & $0.30 \mathrm{~b}$ & $21.6 \mathrm{a}$ & 1.9 \\
\hline CLX L745 & 10.2 & $11.5 \mathrm{ab}$ & $1.12 \mathrm{ab}$ & 22.2 & $0.48 \mathrm{ab}$ & $0.39 a b$ & $19.1 \mathrm{~b}$ & 2.1 \\
\hline Mare & 10.1 & $10.3 \mathrm{abc}$ & 1.02 b & 20.6 & $0.50 a$ & $0.41 \mathrm{a}$ & $18.4 \mathrm{~b}$ & 1.9 \\
\hline Luna & 10.0 & $9.7 \mathrm{bc}$ & $0.97 \mathrm{~b}$ & 19.6 & $0.51 \mathrm{a}$ & $0.41 \mathrm{a}$ & $19.4 \mathrm{~b}$ & 1.9 \\
\hline Gladio & 9.7 & $9.7 \mathrm{bc}$ & $1.00 \mathrm{~b}$ & 19.4 & $0.50 \mathrm{a}$ & $0.40 \mathrm{a}$ & 19.4 b & 1.9 \\
\hline Sirio & 9.5 & $9.5 \mathrm{bc}$ & $1.00 \mathrm{~b}$ & 19.0 & $0.50 \mathrm{a}$ & $0.41 \mathrm{a}$ & $18.8 \mathrm{~b}$ & 1.8 \\
\hline Sprint & 10.4 & $9.4 \mathrm{bc}$ & $0.90 \mathrm{~b}$ & 19.8 & $0.52 \mathrm{a}$ & $0.43 a$ & $18.0 \mathrm{~b}$ & 1.9 \\
\hline Ronaldo & 9.5 & $9.2 \mathrm{bc}$ & $0.97 \mathrm{~b}$ & 18.8 & $0.51 \mathrm{a}$ & $0.41 \mathrm{a}$ & $19.1 \mathrm{~b}$ & 2.0 \\
\hline Marquesa & 10.5 & $8.8 \mathrm{bc}$ & $0.83 \mathrm{~b}$ & 19.3 & $0.55 a$ & $0.45 a$ & $18.0 \mathrm{~b}$ & 2.0 \\
\hline Membo & 9.2 & $8.0 \mathrm{c}$ & 0.87 b & 17.2 & $0.53 a$ & $0.43 a$ & $18.8 \mathrm{~b}$ & 1.8 \\
\hline Creso & 9.7 & $7.6 \mathrm{c}$ & $0.79 \mathrm{~b}$ & 17.4 & $0.56 \mathrm{a}$ & $0.45 a$ & $19.7 \mathrm{ab}$ & 2.0 \\
\hline Significance & n.s. & $* * *$ & $* *$ & n.s. & ** & $* * *$ & * & n.s. \\
\hline Mean & 9.7 & 9.7 & 1.00 & 19.4 & 0.50 & 0.41 & 19.1 & 1.9 \\
\hline SEm \pm & 0.8 & 0.7 & 0.10 & 1.13 & 0.02 & 0.02 & 0.4 & 0.2 \\
\hline HSD & 4.2 & 2.8 & 0.49 & 5.8 & 0.11 & 0.09 & 2.1 & 0.8 \\
\hline
\end{tabular}

$G$ - grain yield (rough grain); $S$ - straw yield; $B$ - total biomass yield; $H I$ - harvest index for rough grain; $H I^{\prime}$ - harvest index for husked grain; n.s. - no significant difference; means with different letters in the same column differ significantly at ${ }^{*} P=0.05$, ${ }^{* *} P=0.01$; *** $P=0.001$, respectively; SEm \pm standard mean error; HSD - critical value for comparison

is in line with results described by Hay (1995), and mean S/ $G^{\prime}$ was 1.25 . Correlation with the corrected grain yield $\left(G^{\prime}\right)$ was also significant in both cases, with similar regression coefficients. Considering both types of fibrous byproducts (straw + husk), the average yield was $11.6 \mathrm{t} \cdot \mathrm{ha}^{-1}$, ranging significantly according to variety. An average of $1.20 \mathrm{t}$ of fibrous byproducts per tonne of grain was determined, which is in compliance with results observed by Matsumura et al. (2005).

Fibre content and composition, ash content and relative feed value (RFV) of rice straw according to variety

Results are shown in Table 2. Variety had significant influence on fibre content and composition, which is in line with that reported by others (Sarnklong et al., 2010; Vadiveloo and Phang, 1996). Fibre content and composition correlated neither with $\mathrm{S}$ nor with $\mathrm{BPI}$.

$C F, N D F, A D F, A D L, C$ and $H$ were lower than those reported by Fedna (2013) for wheat and barley straw (36.0\%, $72.0 \%, 46.4 \%, 8.4 \%, 38.0 \%, 25.6 \%)$, the most abundant crop byproducts in Spain (Palumbo et al., 2015), which is in line with that quoted by Bakker et al. (2013). Nevertheless, potential yield of cellulose from rice straw (mean of $3.2 \mathrm{t} \cdot \mathrm{ha}^{-1}$, with significant differences among varieties) is quite higher than from winter cereals straw $\left(1.5 \mathrm{t} \cdot \mathrm{ha}^{-1}\right)$, considering a straw yield of $4.0 \mathrm{t} \cdot \mathrm{ha}^{-1}$ for wheat and barley (Townsend et al., 2017). Furthermore, approx. $0.5 \mathrm{t} \cdot \mathrm{ha}^{-1}$ of cellulose could be also obtained from rice husk, taking into account the average husk yield $\left(1.9 \mathrm{t} \cdot \mathrm{ha}^{-1}\right)$ and $35.6 \%$ of cellulose (Matías et al., 2018). Cellulose content of rice straw was quite lower than that (41-57\%) stated by Liu et al. (2013) and similar to that reported by others (Bakker et al., 2013; Sarnklong et al., 2010; Abou-El-Enin et al., 1999; Vadiveloo and Phang, 1996). Hemicellulose content was quite lower than that reported by others (Liu et al., 2013, Bakker et al., 2013; Sarnklong et al., 2010; Abou-El-Enin et al., 1999; Vadiveloo and Phang, 1996). Lignin content showed values in line with those determined by Vadilevo and Phang (1996), but lower than those quoted in some papers (Hasanjanzadeha et al., 2014; Liu et al., 2013; Bakker et al., 2013) and slightly higher than the average value calculated by Abou-El-Enin et al. (1999). High lignocellulosic content in rice straw has been reported to be a limitation for its feeding use by Vadiveloo et al. (2009). However, average lignocellulosic content in rice straw in this work (58.8\%) was lower than that reported for wheat and barley straw (72.0\%) by Fedna (2013). On the contrary, average ash content in rice straw (13.7\%) was higher than that stated by Fedna (2013) for winter cereals $(7.2 \%)$. Ash content varied significantly from $12.0 \%$ to $16.1 \%$, which are in reasonable agreement with values reported by others (Hasanjanzadeha et al., 2014; Bakker et al., 2013; Sarnklong et al., 2010; Vadiveloo, 2000; Vadiveloo and Phang, 1996). RFV values varied significantly among varieties and were higher than those (61.0-68.0) stated by Fekadu et al. (2017) and calculated for wheat and barley straw (68.2) by Fedna (2013). Varietal differences in the nutritional value of rice straw were also reported by Vadiveloo and Phang (1996). In principle, the higher the RFV, the better the quality for feeding uses. However, high ash content in rice straw and its high silica content highly reduce its nutritional value (Vadiveloo et al., 2009).

\section{Baling trials}

The results were $2.9 \mathrm{t} \cdot \mathrm{ha} \mathrm{a}^{-1}$ (2014) and $2.0 \mathrm{t} \cdot \mathrm{ha}^{-1}$ (2015) of baled straw. Differences between years can be explained because, in 2015 , the baling operation was delayed until December due to intense rainfall occurring from September to November $(161.7 \mathrm{~mm})$, most likely resulting in straw 
Table 2 Fibre content and composition, ash content and relative feed value (RFV) of rice straw according to variety

\begin{tabular}{|c|c|c|c|c|c|c|c|c|}
\hline Variety & CF (\%) & Ash (\%) & NDF (\%) & ADF (\%) & ADL (\%) & RFV & C (\%) & H (\%) \\
\hline Marquesa & $31.3 \mathrm{a}$ & $14.7 \mathrm{ab}$ & $60.7 \mathrm{ab}$ & $40.2 \mathrm{ab}$ & $5.7 \mathrm{ab}$ & $88.4 \mathrm{ab}$ & $33.9 \mathrm{abc}$ & $20.5 \mathrm{a}$ \\
\hline Mare & $30.5 \mathrm{ab}$ & $13.8 \mathrm{abc}$ & $62.0 \mathrm{a}$ & $42.1 \mathrm{a}$ & $6.8 \mathrm{ab}$ & $84.2 b$ & $35.3 \mathrm{ab}$ & $19.9 \mathrm{ab}$ \\
\hline Sprint & $30.5 \mathrm{ab}$ & $13.2 \mathrm{bc}$ & $61.6 \mathrm{a}$ & $40.3 \mathrm{ab}$ & $6.4 \mathrm{ab}$ & $87.0 \mathrm{ab}$ & $34.0 \mathrm{abc}$ & $21.2 \mathrm{a}$ \\
\hline CLX L745 & $30.3 \mathrm{ab}$ & $16.1 \mathrm{a}$ & $60.1 \mathrm{ab}$ & $41.7 \mathrm{a}$ & $6.4 \mathrm{ab}$ & $87.6 \mathrm{ab}$ & $36.0 \mathrm{a}$ & $18.5 \mathrm{ab}$ \\
\hline Creso & $28.5 \mathrm{ab}$ & $14.3 \mathrm{abc}$ & $57.8 \mathrm{ab}$ & $39.2 \mathrm{ab}$ & $6.9 \mathrm{ab}$ & $94.4 \mathrm{ab}$ & $32.3 \mathrm{abc}$ & $18.6 \mathrm{ab}$ \\
\hline Gladio & $27.7 \mathrm{ab}$ & $12.6 \mathrm{bc}$ & $59.3 \mathrm{ab}$ & $38.8 \mathrm{ab}$ & $6.6 \mathrm{ab}$ & $92.2 \mathrm{ab}$ & $32.3 \mathrm{abc}$ & $20.4 \mathrm{ab}$ \\
\hline Ronaldo & $27.4 \mathrm{~b}$ & $13.2 \mathrm{bc}$ & $57.9 \mathrm{ab}$ & $37.8 \mathrm{ab}$ & $6.4 \mathrm{ab}$ & $95.6 \mathrm{ab}$ & $31.4 \mathrm{bc}$ & $20.1 \mathrm{ab}$ \\
\hline Gavella & $27.3 \mathrm{~b}$ & $12.0 \mathrm{C}$ & $58.1 \mathrm{ab}$ & $36.1 \mathrm{~b}$ & $5.2 \mathrm{~b}$ & $97.4 \mathrm{ab}$ & $31.0 \mathrm{c}$ & $21.9 a$ \\
\hline Membo & $27.0 \mathrm{~b}$ & $14.4 \mathrm{ab}$ & $55.0 \mathrm{~b}$ & $38.2 \mathrm{ab}$ & $7.3 \mathrm{a}$ & $100.5 \mathrm{a}$ & $31.0 \mathrm{c}$ & $16.8 \mathrm{~b}$ \\
\hline Luna & $26.9 \mathrm{~b}$ & $12.8 \mathrm{bc}$ & $56.7 \mathrm{ab}$ & $38.2 \mathrm{ab}$ & $7.4 \mathrm{a}$ & $97.4 \mathrm{ab}$ & $31.0 \mathrm{c}$ & $18.6 \mathrm{ab}$ \\
\hline Sirio & $26.9 \mathrm{~b}$ & $13.9 \mathrm{abc}$ & $57.6 \mathrm{ab}$ & $36.4 \mathrm{~b}$ & $6.3 \mathrm{ab}$ & $97.9 \mathrm{ab}$ & $30.1 \mathrm{c}$ & $21.1 \mathrm{a}$ \\
\hline Significance & $* * *$ & $* * *$ & $* *$ & $* * *$ & $* *$ & $* *$ & $* * *$ & $* * *$ \\
\hline Mean & 28.6 & 13.7 & 58.0 & 39.0 & 6.5 & 92.9 & 32.5 & 19.8 \\
\hline SEm \pm & 0.76 & 0.48 & 1.17 & 0.92 & 0.38 & 2.89 & 0.81 & 0.74 \\
\hline HSD & 3.75 & 2.38 & 5.76 & 4.54 & 1.85 & 14.2 & 3.97 & 3.65 \\
\hline
\end{tabular}

CF - crude fibre; NDF - neutral detergent fibre; ADF - acid detergent fibre; ADL - lignin acid detergent; RFV - relative feed value; $C$ - cellulose; $\mathrm{H}$ - hemicellulose; means with different letters in the same column differ significantly at ${ }^{* *} P=0.01 ; * * * P=0.001 ; \mathrm{SEm} \pm$ standard mean error; HSD - critical value for comparison

loss. These results are lower than those (approx. $4 \mathrm{t} \cdot \mathrm{ha}^{-1}$ ) reported for winter cereals (Garstang et al., 2009). Average characteristics of the bales (weight, humidity content and density on fresh basis) were (in 2014-2015): 18.8-19.5 kg, $21.0-21.3 \%$ and $117.9-127.1 \mathrm{~kg} \cdot \mathrm{m}-3$. The baled yields $(62 \%$ in 2014 and $68 \%$ in 2015) were lower than the available straw for baling (4.9 t.ha ${ }^{-1}$ in 2014 and 2.9 t.ha ${ }^{-1}$ in 2015). Straw losses during the baling operation could be due to several reasons. Despite the low tractor speed (approx. 1.5 $\mathrm{km} \cdot \mathrm{h}-1$ ), the high amount of straw on the windrows with relatively high moisture content (around 25\%) saturated the bale-chamber. Nevertheless, according to Singh et al. (2016), the moisture level was relatively good for baling in terms of adverse conditions. On the other hand, straw losses probably also occurred during the pick-up step due to relatively high moisture content. Available straw amount for baling was quite lower than the straw yield, but it should be noted that rice is usually cut relatively high due to flooding conditions of rice fields. In order to increase the baled straw yield of rice crop, some modifications in baler machine should be developed, such as higher feeding and compression capacity. Furthermore, a special crop management should be carried out to favour an earlier harvest for avoiding autumn rains, trying to harvest at a higher height.

\section{Conclusions}

Rice crop has high straw yield under Mediterranean conditions, approx. 10 t.ha ${ }^{-1}$, with significant differences among varieties. Individual varieties showed significant impacts on majority of evaluated parameters, which makes estimations based on average rice crop values less accurate. Significant relationships $(P<0.01)$ were observed between both BPI and G, but these should be taken into account with caution, because less than $30 \%$ of the BPI variation could be explained by G. New works should be carried out to confirm the stability of those relationships between varieties. Straw fibre content and composition were influenced neither by S nor by G. The RFV was relatively good (92.9), although average ash content was high (13.7\%). Rice straw showed to be a good eco-friendly source of lignocellulosic biomass in Europe, with approx. $32.5 \%$ of cellulose. More than $3.0 \mathrm{t} \cdot \mathrm{ha}^{-1}$ of cellulose could be potentially obtained from rice straw. Nevertheless, results of straw collection were low. Less than $3.0 \mathrm{t} \cdot \mathrm{ha}^{-1}$ could be baled. To increase the amount of baled straw, a special crop management should be carried out and improvements in baling machine should be developed.

\section{Acknowledgements}

This work was supported by the WALEVA LIFE + project (LIFE13 ENV/ES/001165). The authors are grateful to Don Benito Farmers Association (Spain) for their helpful cooperation.

\section{References}

ABOU-EL-ENIN, O. H. - FADE, J. G. - MACKILL, D. J. 1999. Differences in chemical composition and fibre digestion of rice straw with, and without, anhydrous ammonia from 53 rice varieties. In Animal Feed Science and Technology, vol. 79, pp. 129-136.

ABRAHAM, A. - MATHEW, A. K. - SINDHU, R. - PANDEY, A. - BINOD, P. 2016. Potential of rice straw for bio-refining: An overview. In Bioresource Technology, vol. 215, pp. 29-36.

AMANULLAH, J. - INAMULLAH, Z. 2016. Dry matter partitioning and harvest index differ in rice genotypes with variable rates of phosphorus and zinc nutrition. In Rice Science, vol. 23, no. 2, pp. 78-87. 
BAKKER, R. R. C. - ELBERSEN, H. W. - POPPENS, R. P. - LESSCHEN, J. P. 2013. Rice straw and wheat straw. Potential feedstocks for the biobased economy. Netherlands Agency.

BELOEV, I. - GABROVSKA-EVSTATIEVA, K. - EVSTATIEV, B. 2017 Compensation of $\mathrm{CO}_{2}$ emissions from petrol stations with photovoltaic parks: Cost-benefit and risk analysis. In Acta Technologica Agriculturae, vol. 20, no. 4, pp. 85-90.

BUENO, C. S. - LAFARGE, T. 2009. Higher crop performance of rice hybrids than of elite inbreds in the tropics: 1. Hybrids accumulate more biomass during each phenological phase. In Field Crops Research, vol. 112, pp. 229-237.

DOBERMANN, A. - FAIRHURST, T. H. 2000. Chapter 1.9. Managing Organic Manures, Straw, and Green Manure. In Rice: Nutrient disorders \& nutrient management. Handbook series. Potash \& Phosphate Institute (PPI), Potash \& Phosphate Institute of Canada (PPIC) and International Rice Research Institute (IRRI), pp. 38-42. ISBN 9789810579494.

FAN, J. - MCCONKEY, B. - JANZEN, H. - TOWNLEY-SMITH, L. WANG, H. 2017. Harvest index-yield relationship for estimating crop residue in cold continental climates. In Field Crops Research, vol. 204, pp. 153-157.

FAGERIA, N. K. - MOREIRA, A. - COELHO, A. M. 2011. Yield and yield components of upland rice as influenced by nitrogen sources. In Journal of Plant Nutrition, vol. 34, pp. 361-370.

FEDNA. 2013. FEDNA - Spanish Foundation for the Development of Animal Nutrition - standards for the formulation of compound feed (Normas Fedna - Fundación Española para el Desarrollo de la Nutrición Animal - para la formulación de piensos compuestos).

FEKADU, D. - WALELEGN, M. - TEREFE, G. 2017. Indexing Ethiopian feed stuffs using relative feed value: Dry forages and roughages, energy supplements, and protein supplements. In Journal of Biology, Agriculture and Healthcare, vol. 7, no. 21, pp. 57-60.

GARSTANG, J. - MACKIE, E. - MATTHEWS, R. - PROCTER, C. H. RANDLE, T. - SMITH, C. - TUBBY, I. - WILSON, L. 2009. Bioenergy Review - Mapping Work. Science report: SC070001/SR2. Environment Agency.

HASANJANZADEHA, H. - HEDJAZIA, S. - ASHORIB, A. MAHDAVIC, S. - YOUSEFI, H. 2014. Effects of hemicellulose preextraction and cellulose nanofiber on the properties of rice straw pulp. In International Journal of Biological Macromolecules, vol. 68 pp. 198-204.

HAY, R. K. M.1995. Harvest index: A review of its use in plant breeding and crop physiology. In Annals of Applied Biology, vol. 26 pp. 197-216.

HEGAZY, R. - SNADRO, J.M. 2016. Rice straw collection. International Rice Research Institute Crop and Environmental Sciences Division Postharvest Unit.

HUSSAIN, S. - FUJII, T. - MCGOEY, S. - YAMADA, M. - RAMZAN, M. - AKMAL, M. 2014. Evaluation of different rice varieties for growth and yield characteristics. In Journal of Animal and Plant Sciences, vol. 24, no. 5, pp. 1504-1510.

ION, V. - DICU, G. - DUMBRAVĂ, M. - TEMOCICO, G. - ALECU, I. N. - BĂŞA, A. G. - STATE, D. 2015. Harvest index at maize in different growing conditions. In Romanian Biotechnological Letters, vol. 20, no. 6, pp. 1-10.

JUNTA DE EXTREMADURA. 2017. Agriculture and livestock of Extremadura in 2016 (La agricultura y la ganadería extremeñas 2016). Fundación CB. 364 pp.

KINIRY, J. R. - MC-CAULEY, G. - XIE, Y. - ARNOLD, J. G. 2001. Rice parameters describing crop performance of four rice cultivars. In Agronomy Journal, vol. 93, pp. 1354-1361.

LIU, Z. - LIU, X. - FEI, B. - JIANG, Z. - CAI, Z. - YUA, Y. 2013. The properties of pellets from mixing bamboo and rice straw. In Renewable Energy, vol. 55, pp. 1-5.
MATÍAS, J. - GARCÍA, A. - GONZÁLEZ, D. - GARCÍA, J. HERNÁNDEZ-GARCÍA, F. I. - IZQUIERDO, M. 2018. Use of rice husk in Iberian pigs during the pre-montanera period for welfare diets. Preliminary results. In Archivos de Zootecnia, Proceedings $9^{\text {th }}$ International Symposium on the Mediterranean Pig, Portalegre (Portugal), pp. 37-40.

MATSUMURA, Y. - MINOWAB, T. - YAMAMOTO, H. 2005. Amount, availability, and potential use of rice straw (agricultural residue) biomass as an energy resource in Japan. In Biomass and Bioenergy, vol. 29, pp. 347-354.

MORENO-GARCÍA, B. - GUILLÉN, M. - QUÍLEZ, D. 2017. Response of paddy rice to fertilisation with pig slurry in northeast Spain: Strategies to optimise nitrogen use efficiency. In Field Crops Research, vol. 208, pp. 44-54.

OLK, D. C. - VAN KESSEL, C. - BRONSON, K. F. 2000. Managing soil organic matter in rice and non-rice soils: Agronomic questions. In Carbon and Nitrogen Dynamics in Flooded Soils. International Rice Research Institute, Los Baños, Philippines, pp. 27-47. ISBN 9712201406.

OSORIO, J. F. 2007. Evolution of growth, grain yield and partition of photosynthates in 14 varieties of rice representing various breeding cycles in Colombi. Universidad de Colombia, Palmira. 135 pp. (In Spanish: Evolución del crecimiento, rendimiento de grano y partición de fotosintatos en 14 variedades de arroz representantes de diversos ciclos de mejoramiento en Colombia).

PALUMBO, M. - AVELLANEDA, J. - LACASTA, A. M. 2015.Availability of crop by-products in Spain: New raw materials for natural thermal insulation. In Resources, Conservation and Recycling, vol. 99, pp. 1-6.

PRASAD, P. V. V. - BOOTE, K. J. - ALLEN, L. H - SHEEHY, J. E. THOMAS, J. M. G. 2006. Species, ecotype and cultivar differences in spikelet fertility and harvest index of rice in response to high temperature stress. In Field Crops Research, vol. 95, pp. 398-411.

RAHIMI-AJDADI, F. - ASLI-ARDEH, A. A. E. - AHMADI-ARA, A. 2018. Effect of varying parboiling conditions on head rice yield for common paddy varieties in Iran. In Acta Technologica Agriculturae, vol. 21, no. 1, pp. 1-7.

SARNKLONG, C. - CONE, J. W. - PELLIKAAN, W. - HENDRIKS, W. H. 2010. Utilization of rice straw and different treatments to improve its feed value for ruminants: A review. In Asian-Australasian Journal of Animal Science, vol. 23, no. 5, pp. 680-692.

SINGH, D. K - GUPTA, S. - NANDA, G. - SHARMA, Y. - SINGH, V. V. BISARYA, D. 2017. Evaluation of rice varieties for yield under organic farming in Tarai. In International Journal of Current Microbiology and Applied Science, vol. 6, no. 4, pp. 734-738.

SINGH, R. - SRIVASTAVA, M. - SHUKLA, A. 2016. Environmental sustainability of bioethanol production from rice straw in India: A review. In Renewable and Sustainable Energy Reviews, vol. 54, pp. 202-216.

TOWNSEND, T. J. - SPARKES, D. L. - WILSON, P. 2017. Food and bioenergy: Reviewing the potential of dual purpose wheat crops. In GCB Bioenergy, vol. 9, pp. 525-540.

VADIVELOO, J. - NURFARIZA, B. - FADEL, J. G. 2009. Nutritional improvement of rice husks. In Animal Feed Science and Technology, vol. 151, no. 3, pp. 299-305.

VADIVELOO, J. 2000. Nutritional properties of the leaf and stem of rice straw. In Animal Feed Science and Technology, vol. 83, pp. 57-65.

VADIVELOO, J. - PHANG, O. C. 1996. Differences in the nutritive value of two rice varieties as influenced by season and location. In Animal Feed Science and Technology, vol. 61, pp. 247-258.

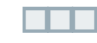

